\title{
NAT2 Genotype Pattern among Tuberculosis Patients Receiving Fixed-Dose Combination of Antituberculosis
}

\author{
I Gusti Ayu Artini ${ }^{1}$, I Gusti Ngurah Bagus Artana ${ }^{2}$ \\ ${ }^{1}$ Pharmacology Department, Medical Faculty, Udayana University, Indonesia \\ ${ }^{2}$ Department of Internal Medicine, Medical Faculty, Udayana University, Indonesia
}

\begin{abstract}
Drug-induced liver injury (DILI) has known to be very responsible for more than $50 \%$ of acute liver failure cases in United States. Nowadays DILI's treatment is only focused on supportive therapy as well as stopping the medication responsible for it. The incidence of antituberculosis liver injury (ATLI) in the world was ranging between 13-48\%. Acetylator status and NAT2 genotype pattern related to it were two factors that have strong relationship to ATLI incidence. Slow acetylator was reported to significantly increase ATLI incidence in many studies. The proportion of slow acetylator were varies in many countries, ranging between 6-55\% and these were strongly related to NAT2 genotype pattern. This study aimed to investigate NAT2 genotype pattern in tuberculosis patients receiving fixed-dose combination of antituberculosis. As many as 35 tuberculosis patients attending Outpatient Clinic of Sanglah Hospital were included in this cross sectional study. Identification of NAT2 genotype was performed with PCR-RFLP assay using KpnI and BamHI restriction enzymes. This study reveals the proportion of $N A T 2 * 4 / * 4 ; * 4 / * 5$ and $* 5 / * 5$ genotype were $54.3 \% ; 37.1 \%$; dan $8.6 \%$, respectively, whereas the proportion of $\mathrm{NAT} 2 * 4 / * 4 ; * 4 / * 7$ and $* 7 / * 7$ genotype were $11.4 \%$; $71.4 \%$; dan $17.2 \%$, respectively.
\end{abstract}

Keywords: antituberculosis, liver injury, $\mathrm{N}$-acetyl transferase 2, acetylator, gene

\section{Introductions}

Drug-induced liver injury (DILI) has known to be very responsible for more than $50 \%$ of acute liver failure cases in United States. More than 75\% DILI might result serious disease and required liver transplantation. Nowadays DILI's treatment is only focused on supportive therapy as well as stopping the medication responsible for it. DILI was the most frequent cause of drug withdrawal from the market. One of many drugs related to DILI was antituberculosis. ${ }^{1,2,3}$

The incidence of antituberculosis liver injury (ATLI) in the world was ranging between $13-48 \%$. Acetylator status and NAT2 genotype pattern related to it were two factors that have strong relationship to ATLI incidence. ${ }^{4,5,6,7,8,9}$

Slow acetylator was reported to significantly increase ATLI incidence in many studies. The proportion of slow acetylator were varies in many countries, ranging between $6-55 \%$ and these were strongly related to NAT2 genotype pattern. Slow acetylator were dominant in Brazil and India. ${ }^{4,10}$ Contrary to those result, the dominant acetylation status in China and Japan was fast acetylator. $5,6,8,11,12$

\section{Methods}

As many as 35 tuberculosis patients attended Pulmonary Outpatient Clinic of Sanglah Hospital between June to December 2014 were included in this cross sectional study. All subjects received fixed-dose combination of antituberculosis category 1 . Subjects were selected using consequtive sampling technique. This study was approved by Ethical Committee of Sanglah Hospital.

DNA was isolated using guanidine isothiocyanate methods. The sequences for forward and reverse primer were 5'-GGA
ACA AAT TGG ACT TGG-3' and 5'-TCT AGC ATG AAT CAC TCT GC-3', respectively. DNA chains were denatured at $94^{\circ} \mathrm{C}$ for 5 minutes, followed by 35 cycle of reaction $\left(94^{\circ} \mathrm{C}\right.$ denaturation for 1 minute, $50^{\circ} \mathrm{C}$ annealing for 1 minute, $72^{\circ} \mathrm{C}$ elongation for 1 minute). Finally ended by final extension at $72^{\circ} \mathrm{C}$ for 10 minutes. PCR product was digested using KpnI and BamHI restriction enzyme. The mixture was incubated at $37^{\circ} \mathrm{C}$ for 90 minutes. Electrophoresis of PCR-RFLP product using $2 \%$ agarose gel.

The wild type NAT $2 * 4 / * 4$, heterozygote $* 4 / * 5$ and homozygote mutant $* 5 / * 5$ genotype showed 2 bands (662 and $430 \mathrm{bp}$ ), 3 bands (1092, 662 and $430 \mathrm{bp})$, and 1 band $(1092 \mathrm{bp})$, respectively. The wild type NAT2 $* 4 / * 4$, heterozygote $* 4 / * 7$ and homozygote mutant $* 7 / * 7$ genotype showed 2 bands ( 814 dan 278 bp), 3 bands (1092, 814 dan $278 \mathrm{bp}$ ), and 1 band (1092 bp), respectively.

\section{Results and Discussions}

As many as 35 tuberculosis patients were included in our study. Subject characteristics were shown on Table 1.

Table 1: Subject characteristics

\begin{tabular}{|l|rl|c|}
\hline No & \multicolumn{2}{|c|}{ Subject Characteristics } & $\mathrm{n}(\%)$ \\
\hline 1 & Sex & $20(57.1)$ \\
& $-\quad$ Male & $15(42.9)$ \\
\hline 2 & Age & $16(45.7)$ \\
& $-\quad<30$ y.o & $19(54.3)$ \\
\hline 3 & Initial BTA status & $21(60)$ \\
& $-\quad$ Positive & $14(40)$ \\
\hline
\end{tabular}

This study revealed the proportion of NAT $2 * 4 / * 4 ; * 4 / * 5$ and $* 5 / * 5$ genotype were $54.3 \% ; 37.1 \%$; and $8.6 \%$, respectively (Table 2 ), whereas the proportion of NAT $2 * 4 / * 4 ; * 4 / * 7$ and 


\section{International Journal of Science and Research (IJSR) \\ ISSN (Online): 2319-7064}

Index Copernicus Value (2013): 6.14 | Impact Factor (2014): 5.611

*7/*7 genotype were $11.4 \% ; 71.4 \%$; and $17.2 \%$, respectively (Table 3). These results indicated that most subjects were fast acetylator. It means in most subjects the metabolism were very fast and therefore had a lower risk of hepatotoxicity. ${ }^{11}$

Table 2: NAT2*5 genotype pattern in tuberculosis patients receiving fixed-dose combination of antituberculosis

\begin{tabular}{|l|c|c|}
\hline \multicolumn{1}{|c|}{ NAT2 $* 5$ genotype } & Frequency $(\mathrm{n})$ & Proportion $(\%)$ \\
\hline Wild type & 19 & 54.3 \\
\hline Mutant heterozygote & 13 & 37.1 \\
\hline Mutant homozygote & 3 & 8.6 \\
\hline
\end{tabular}

Table 3: NAT2*7 genotype pattern in tuberculosis patients receiving fixed-dose combination of antituberculosis

\begin{tabular}{|c|c|c|}
\hline NAT2*7 genotype & Frequency $(\mathrm{n})$ & Proportion (\%) \\
\hline Wild type & 4 & 11.4 \\
\hline Mutant heterozygote & 25 & 71.4 \\
\hline Mutant homozygote & 6 & 17.2 \\
\hline
\end{tabular}

On INH metabolism process, NAT2 enzyme together with CYP2E1, GSTM1 and GSTT1 catalyzed the metabolism of INH in liver. INH actually was a prodrug that required further biotransformation into its active form acetyl-INH (catalyzed by NAT2 enzyme) and hydrazine. Hydrazine and acetyl-INH would then be converted into acetylhydrazine and furthermore into diacetylhydrazine (by NAT2). Acetylhydrazine was also converted by CYP2E1 into toxic metabolite that required detoxification first (by GST enzyme) before excreted. ${ }^{11,13,14}$

The proportion of ATLI in Brazil was $15.6 \%{ }^{4}$, whereas in China, the proportion of ATLI in many studies revealed varies result ranging between $14-48 \%$. $5,6,7,8,9$

Many factors responsible for ATLI incidence, one of which was genetic factor. Some genetic variations responsible for higher risk of ATLI, specifically on gene related to antituberculosis metabolism such as NAT2, CYP2E1, GSTM1 and GSTT1 gene. NAT2, CYP2E1, GSTM1 and GSTT1 were actually enzymes that needed for isoniazid (INH) metabolism. ${ }^{1,3,6,15}$

The relationship between NAT2 polymorphism and acetylator status in ATLI had also reported in many studies, but the results were inconsistent. Some of the studies revealed that there was no significant association between NAT2 polymorphism and ATLI. ${ }^{5}$ In the other hand, many studies reported that slow acetylator of NAT2 was the most significant risk factor for ATLI incidence. ${ }^{4,6,8,11,12,16} \mathrm{~A}$ metaanalyses conducted by Sun et al. (2008) showed that slow acetylator of NAT2 together with genotype c1/c1 CYP2E1 and GSTM1 null signifiantly increased ATLI incidence. $^{17}$

The proportion of slow acetylator varied in many studies. Slow acetylator proportion in China ranging between 20$29 \%$. ${ }^{5,6,8}$ Different result was reported in Japan. The proportion of slow acetylator in Japan was only 6-9\%. ${ }^{11,12}$ Despite the different result, slow acetylator status in China and Japan were not the dominant acetylator status. Different result was showed in the study conducted in Brazil. Slow acetylator was the dominant acetylator status in Brazil with proportion 55\%. Similar result was showed by study conducted in India, the proportion of slow acetylator was $55 \%{ }^{4,10}$

\section{Conclusions}

In this study the dominant genotype of NAT2 was $* 4 / * 4$ $(54.3 \%)$ and $* 4 / * 7(71.4 \%)$.

\section{References}

[1] Lee WM. Drug-induced hepatotoxicity. New England Journal of Medicine. 2003; 349:474-485.

[2] Musana KA, Yale SH, Abdulkarim AS. Tests of liver injury. Clinical Medicine and Research. 2004; 2(2):129-131.

[3] Navarro VJ dan Senior JR. Drug-related hepatotoxicity. New England Journal of Medicine. 2006; 354:731-739.

[4] Teixeira RLF, Morato RG, Cabello PH, Munizz LMK, Moreira ASR, Kritski AL, Mello FCQ, Suffys PN, deMiranda AB, Santos AR. Genetic polymorphisms of NAT2, CYP2E1 and GST enzymes and the occurrence of antituberculosis drug-induced hepatitis in Brazilian TB patients. Mem Inst Oswaldo Cruz. 2011; 106(6):716-724.

[5] Lv X, Tang S, Xia Y, Zhang Y, Wu S, Yang Z, Li X, Tu D, Chen Y, Deng P, Ma Y, Chen D, Chen R, Zhan S. NAT2 genetic polymorphisms and antituberculosis drug-induced hepatotoxicity in Chinese community population. Annals of Hepatology. 2012; 11(5):700707.

[6] Huang YS, Chern HD, Su WJ, Wu JC, Lai SL, Yang SY, Chang FY, Lee SD. Polymorphism of the Nacetyltransferase 2 gene as a susceptibility risk factor for antituberculosis drug-induced hepatitis. Hepatology. 2002; 35:883-889.

[7] Wang T, Yu HT, Wang W, Pan YY, He LX, Wang ZY. Genetic polymorphisms of cytochrome p450 and glutathione s-transferase associated with antituberculosis drug-induced hepatotoxicity in Chinese tuberculosis patients. The Journal of International Medical Research. 2010; 38:977-986

[8] Lee SW, Chung LSC, Huang HH, Chuang TY, Liou YH, Wu LSH. NAT2 and CYP2E1 polymorphisms and susceptibility to first line antituberculosis drug-induced hepatitis. International Journal of Tuberculosis and Lung Disease. 2010; 14(5):622-626.

[9] Bose PD, Sarma MP, Medhi S, Das BC, Husain SA, Kar P. Role of polymorphic $N$-acetyl transferase 2 and cytochrome P4502E1 gene in antituberculosis treatment-induced hepatitis. Journal of Gastroenterology and Hepatology. 2011; 26(2):312318.

[10] Singh N, Dubey S, Chinnaraj S, Golani A, Maitra A. Study of NAT2 gene polymorphisms in an Indian population: association with plasma isoniazid concentration in a cohort of tuberculosis patients. Molecullar Diagnostic and Therapy. 2009; 13(1):49-58

[11] Fukino K, Sasaki Y, Hirai S, Nakmura T, Hashimoto M, Yamagishi F, Ueno K. Effect of $\mathrm{N}$-acetyltransferase 2 (NAT2), CYP2E1 and glutathione s-transferase (GST) genotypes on the serum concentrations of 


\section{International Journal of Science and Research (IJSR) \\ ISSN (Online): 2319-7064}

Index Copernicus Value (2013): 6.14 | Impact Factor (2014): 5.611

isoniazid and metabolites in tuberculosis patients. The Journal of Toxicological Sciences. 2008; 33(2):187195.

[12] Hiratsuka M, Kishikawa Y, Takekuma Y, Matsuura M, Narahara K, Inoue T, Hamdy SI, Endo N, Goro J, Mizugaki M. Genotyping of the N-acetyltransferase2 polymorphism in the prediction of adverse drug reaction to isoniazid in Japanese patients. Drug Metabolism and Pharmacokinetic. 2003; 17(4):357362.

[13] Caws M, Tho DQ, Duy PM, Lan NTN, Hoa DV, Torok ME, Chau TTH, Chau NVV, Chinh NT, FarrarJ. PCRrestriction fragment length polymorphism for rapid, low cost identification of isoniazid-resistant Mycobacterium tuberculosis. Journal of Clinical Microbiology. 2007; 45(6):1789-1793.

[14] Ramaswamy SV, Reich R, Dou SJ, Jasperse L, Pan X, Wanger A, Quitugua T, Graviss EA. Single nucleotide polymorphisms in genes associated with isoniazid resistance in Mycobacterium tuberculosis. Antimicrobial Agents and Chemotherapy. 2003; 47(4):1241-1250.

[15] Arbex MA, Varella MCL, deSiqueira HR, de Mello FAF. Antituberculosis drugs: drug interaction, adverse effects and use in special situations. Journal of Brasil Pneumology. 2010; 36(5):626-640.

[16] Cai Y, Yi JY, Zhou CH, Shen XZ. Pharmacogenetic study of drug-metabolizing enzyme polymorphism on the risk of antituberculosis drug-induced liver injury: a meta-analysis. Plos One. 2012; 7(10):e47769.

[17] Sun F, Chen Y, Xiang Y, Zhan S. Drug metabolizing enzyme polymorphisms and predisposition to antituberculosis drug-induced liver injury: a meta analysis. International Journal of Tuberculosis and Lung Disease. 2008; 12(9):994-1002. 